\title{
The reform study: a case study of embedded trials
}

\author{
Sarah Cockayne ${ }^{1 *}$, Joy Adamson ${ }^{1}$, Belen Corbacho ${ }^{1}$, Caroline Fairhurst $^{1}$, Lisa Farndon², Kate Hicks ${ }^{1}$, \\ Anne-Maree Keenan ${ }^{3,4}$, Sally Lamb ${ }^{5}$, Lorraine Loughrey ${ }^{3,4}$, Caroline Mclntosh ${ }^{6}$, Hylton Menz ${ }^{7}$, Anthony Redmond ${ }^{3,4}$, \\ Sara Rodgers ${ }^{1}$, Wesley Vernon ${ }^{2}$, Jude Watson ${ }^{1}$, David Torgerson ${ }^{1}$
}

From 3rd International Clinical Trials Methodology Conference

Glasgow, UK. 16-17 November 2015

Evaluation of interventions to enhance recruitment or reduce attrition within randomised controlled trials is uncommon. A number of initiatives have tried to increase this evidence base by encouraging the embedding of such trials within trials evaluating healthcare interventions.

The NIHR-funded REFORM study recruited and followed up participants by mailing out invitation packs and questionnaires to participants. We undertook four embedded studies during the recruitment and follow-up phases: (1) Exploration of the feasibility and validity of the EQ5D-5L: 332 participants were sent a baseline questionnaire containing both the EQ5D-5L and the EQ5D-3L; (2) Two embedded trials evaluating i) the effectiveness of an enhanced patient information sheet (PIS) and ii) prenotification with a study newsletter, to increase recruitment to the trial; and (3) An embedded factorial trial evaluating the effectiveness of a Post-it ${ }^{\circledR}$ note and/or newsletter to increase questionnaire response rates and minimise attrition to the trial.

The EQ5D-5L and Post-It ${ }^{\circledR}$ note studies were easily incorporated using in-house funding. The PIS study required $£ 6,500$ funding from the MRC START team. Undertaking these studies did cause some delay to the main study, but not to the detriment of the study. To date, results for only the PIS and pre-notification studies are available, and no statistically significant differences have been observed.

We have demonstrated that it can be relatively easy to embed several trials within a trial. Whilst funding in some cases may be an issue, can provide useful learning

${ }^{1}$ University of York, York, UK

Full list of author information is available at the end of the article experiences for inexperienced researchers and inform future studies and they do produce academic publications.

\section{Authors' details}

${ }^{1}$ University of York, York, UK. ${ }^{2}$ Sheffield Teaching Hospitals, Sheffield, UK. ${ }^{3} \mathrm{NIHR}$ Leeds Musculoskeletal Biomedical Research Unit, Leeds, UK. ${ }^{4}$ Leeds Institute of Rheumatic and Musculoskeletal Medicine, Leeds, UK. ${ }^{5}$ University of Oxford, Oxford, UK. ${ }^{6} \mathrm{NUI}$ Galway, Galway, Ireland. 'La Trobe University, Bundoora, Australia.

Published: 16 November 2015

doi:10.1186/1745-6215-16-S2-P174

Cite this article as: Cockayne et al.: The reform study: a case study of embedded trials. Trials 2015 16(Suppl 2):P174.

\section{Submit your next manuscript to BioMed Central and take full advantage of: \\ - Convenient online submission \\ - Thorough peer review \\ - No space constraints or color figure charges \\ - Immediate publication on acceptance \\ - Inclusion in PubMed, CAS, Scopus and Google Scholar \\ - Research which is freely available for redistribution

() Biomed Central

C 2015 Cockayne et al. This is an Open Access article distributed under the terms of the Creative Commons Attribution License (http:// creativecommons.org/licenses/by/4.0), which permits unrestricted use, distribution, and reproduction in any medium, provided the original work is properly cited. The Creative Commons Public Domain Dedication waiver (http://creativecommons.org/publicdomain/ zero/1.0/) applies to the data made available in this article, unless otherwise stated. 